\title{
Assessment of the Depth and Rate of Corrosion in Steel Reinforcement of Reinforced Concrete Culverts
}

\author{
Alexandr Vasiliev (iD) 1 , Svetlana Daškevič (iD) 2* \\ ${ }^{1}$ Department "Construction and Architecture", NIL "Diagnostics, \\ Test and Research of Building Materials and Constructions" \\ under the name of Professor I. A. Kudryavtsev, \\ The Belarusian State University of Transport, Gomel, Republic of Belarus \\ ${ }^{2}$ Department of Roads, Vilnius Gediminas Technical University, Vilnius, Lithuania
}

Received 04 February 2020; accepted 31 March 2020

\begin{abstract}
Based on the results of many research years on concrete carbonisation: both immediately after manufacture (using heat-moisture treatment) and in reinforced concrete elements operated for the periods of various length (in an open atmosphere); the effect of carbonisation on the change in the protective properties of concrete in relation to steel reinforcement; for determination of the dependence of the corrosion state of steel reinforcement on the degree of concrete carbonisation in the area of steel reinforcement; the obtained regression dependences of the change (by time in the cross section) of the degree of concrete carbonisation of various classes in strength, - the analysis of the time of the onset of the boundary values of the degrees of concrete carbonisation (strength classes C12/15-C30/37) for the operating conditions of the open atmosphere was performed. Based on it, the regression dependences of the time variation of the depth of corrosion damage of steel reinforcement were construed (for fixed thicknesses of the concrete protective layer). The obtained nature of dependences made it possible to offer, in a general form, the regression dependences of the depth of corrosion damage and corrosion rate of steel reinforcement for concretes (strength classes C12/15-C30/37) for operating conditions in open atmosphere.
\end{abstract}

Keywords: concrete carbonisation, corrosion, durability, rate, reinforced concrete culverts, steel reinforcement.

\section{Introduction}

One of the key factors determining the durability of reinforced concrete culverts is the corrosion rate of steel reinforcement in concrete.

The main process that neutralises concrete in reinforced concrete elements operated in open atmosphere is the carbonisation of concrete, which, by reducing the protective properties of concrete with respect to steel reinforcement, creates conditions for its corrosion.

The process of the development of corrosion in steel reinforcement leads to the reduction of its cross section along with a simultaneous deterioration of its mechanical characteristics. Therefore, the issue of establishing dependence is important: dependence of the corrosion rate of steel reinforcement during carbonisation of the concrete protective layer (thickness of the concrete protective layer; class of concrete in terms of strength and operating conditions of reinforced concrete products).

\section{Main part}

Existing carbonisation assessment techniques based on the phenolphthalein test (PPT) consider only two concrete conditions:

- "healthy", retaining protective properties in relation to steel reinforcement, and

- carbonised, contributing to the emergence and development of corrosion.

These methods do not allow to evaluate the corrosion rate of steel reinforcement and its change in the cross section of concrete.

All studies of concrete carbonisation are based on the basic carbonisation equation that was deduced by the authors of the paper (Alekseev \& Rozental', 1976, p. 154), relying on the theoretical foundations of diffusion kinetics

${ }^{*}$ Corresponding author. E-mail: svetlana.daskevic@vgtu.lt 
and experimental results in which the neutralisation of concrete by carbon dioxide is considered from the standpoint of heterogeneous chemical reactions.

In general, the equation is written as follows:

$$
x=A \sqrt{\tau},
$$

where $x$-thickness of neutralised layer on the phenolphthalein test, $\mathrm{cm} ; A$-coefficient; $\tau$-construction service time, s.

$$
A=\sqrt{\frac{2 D^{\prime} C}{m_{0}}},
$$

where $D^{\prime}$ - effective diffusion coefficient $\mathrm{CO}_{2}, \mathrm{~cm}^{2} / \mathrm{s} ; C$ - atmospheric concentration of $\mathrm{CO}_{2}$ in relative units by volume; $m_{0}-$ concrete reaction capacity, $\mathrm{cm}^{3}$.

Numerous scientists constantly researching various parameters that affect the A coefficient (in terms of concrete composition, technological parameters, operating conditions, etc., to improve the compliance between calculated and actual results). Researchers believe that numerous parameters clarification will bring the calculated values of the carbonisation depth closer to the actual ones. However, it would be logical if the phenolphthalein test (or any other) would show a size of "healthy" concrete rather than an abstract carbonisation value, where the "healthy" concrete retains its protective properties by relation to steel concrete, dividing it by colour with carbonised (that lost protective properties).

Since the carbonisation of concrete is determined by PPT which changes the colour of the concrete, it means that it must show either the limit of the carbonised layer (carbonisation intermittence) or the change in the thickness of the layer that has lost its protective properties with respect to steel reinforcement.

PPT does not show the limit of the concrete carbonisation intermittence. Saturation of concrete with carbon dioxide, carbonisation, continues in depth almost entire life of reinforced concrete products operating in air environments which author has shown in numerous works (Vasil'yev, 2012, 2013, 2016, 2017, 2018, 2019 etc.). Other scientists citing the results of their researches show that the absorption of carbon dioxide over the concrete cross section does not occur linearly but over a complex dependency. And the first to discover it were Alekseev and Rozental' (1976, p. 102), who introduced the dependencies of distribution of bound carbon dioxide over the cross section of cement and sand solution samples with different W/C, although this was not developed further.

PPT is a chemical reaction between phenolphthalein and sodium hydroxide and calcium hydroxide, causing the solution to discolour (colour) at a certain value of the pore liquid alkalinity index $(\mathrm{pH})$, though is does not indicate the intermittence of carbonisation.

During the operation of reinforced concrete, especially for long periods during the opening of protective concrete, quite often steel reinforcement is in a corrosive state of varying degrees of intensity. That happens in the area which after treating the concrete with phenolphthalein has a pronounced colour that is easily explained as it is well known PPT showing a change in alkalinity $\mathrm{pH}$ from 8.5 to 14 , changing colour from colourless to bright raspberry, where the state of steel reinforcement in such a huge range of alkalinity is determined from passive to corrosive high degree of intensity.

In accordance with the thermodynamic calculations of Babushkin (1986, p. 320), corrosion of steel reinforcement is possible at $\mathrm{pH}<11.8$. In the paper (Kudryavtsev \& Bogdanov, 2001, p. 228), according to the results of the study of the cement and sand fraction samples, it was found that the value of the limit of a neutralised layer corresponds to $\mathrm{pH} \approx 10.3$. That is, steel reinforcement, being in the area considered to be protective for steel reinforcement $(\mathrm{pH}=$ $10.3 \div 11.8$ ), can and is corroding under oxygen and air moisture conditions.

Thus, the corrosion rate of steel reinforcement in an open atmosphere in accordance with (DuraCrete 7, 1999):

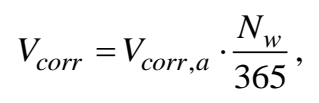

where: $V_{c o r}$, ar is the average corrosion rate of steel reinforcement, $\mathrm{mm} / \mathrm{year}$, determined by the operating conditions; in accordance with (DuraCrete 7, 1999), when operated outdoors, $V_{c o r}$ ar $=0.005 \mathrm{~mm} /$ year, $N_{w}$ is the number of days in a year with precipitation of more than $2.5 \mathrm{~mm}$.

The proposed dependence does not take into account important factors such as:

- concrete class by strength on compression (concrete composition),

- state of protective properties of concrete in relation to steel reinforcement,

- the thickness of the protective layer of concrete.

For the possibility of determining the rate of development of corrosion of steel reinforcement in a carbonised concrete layer, the results of many years of research are used: changes of carbonisation in time over the cross section of concrete, effect of carbonisation on a change in the state of protective properties of concrete in relation to steel reinforcement, states of steel reinforcement (Vasil'yev, 2012, 2013, 2016, 2017, 2018, 2019). 
Based on the revealed dependence of the corrosion state of steel reinforcement (on the degree of concrete carbonisation in the area of steel reinforcement) and the regression dependences obtained (changes by time of the degree of concrete carbonisation in the cross section), the analysis of the timing of the occurrence of the boundary values of the degrees of carbonisation (for different strength classes of concrete) and the dependences of the time variation of the corrosion damage of steel reinforcement (for the thicknesses of the protective layer of concrete 10, 15, 20 and $25 \mathrm{~mm}$ were measured; for concrete strength classes $\mathrm{C}^{12}{ }_{15}-\mathrm{C}^{30} / 37$; for operating conditions in the open atmosphere).

As an example, Figure 1 and Figure 2 show the regression functions of the dependence of the depth of corrosion damage to the steel reinforcement on the thickness of the protective layer of concrete (concrete of strength classes $\mathrm{C}^{16 / 20}$ and $\mathrm{C}^{25 / 30)}$ for the operating conditions in the open atmosphere. Regression dependences for the remaining classes of concrete by strength were obtained similarly. They show that corrosion damage to steel reinforcement develops according to a complex exponential dependence pattern and their rate depends on the thickness of the protective layer of concrete and the strength class of concrete.

Using the obtained dependencies allows (depending on the thickness of the protective layer of concrete of various strength classes):

- to predict the depth of corrosion damage of steel reinforcement over time, and

- evaluate the average corrosion rate of steel reinforcement.

By assuming the planned service life of reinforced concrete products of 50 years, using the obtained dependences of the depth of corrosion damage of steel reinforcement (for boundary values of the thickness of the protective layer of concrete), we obtain the regression dependences of the depth of corrosion damage of steel reinforcement on the thickness of the protective layer of concrete (for concrete strength classes $\mathrm{C}^{12} / 15$ and $\mathrm{C}^{30} / 37$ and the operating conditions in the open atmosphere). The regression dependence graph is shown in Figure 3.

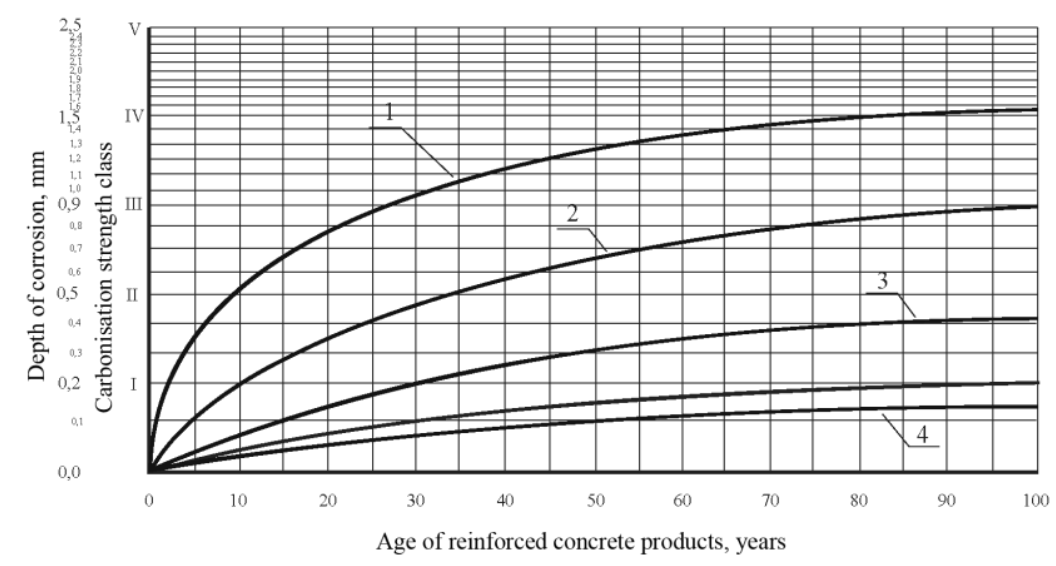

The thickness of the protective layer of concrete: $1-10 ; 2-15 ; 3-20 ; 4-25 \mathrm{~mm}$

Figure 1. Dependences of the depth of steel reinforcement corrosion damage on the thickness of the protective layer of concrete strength class $\mathrm{C}^{16 /}{ }_{20}$ for the open atmosphere conditions

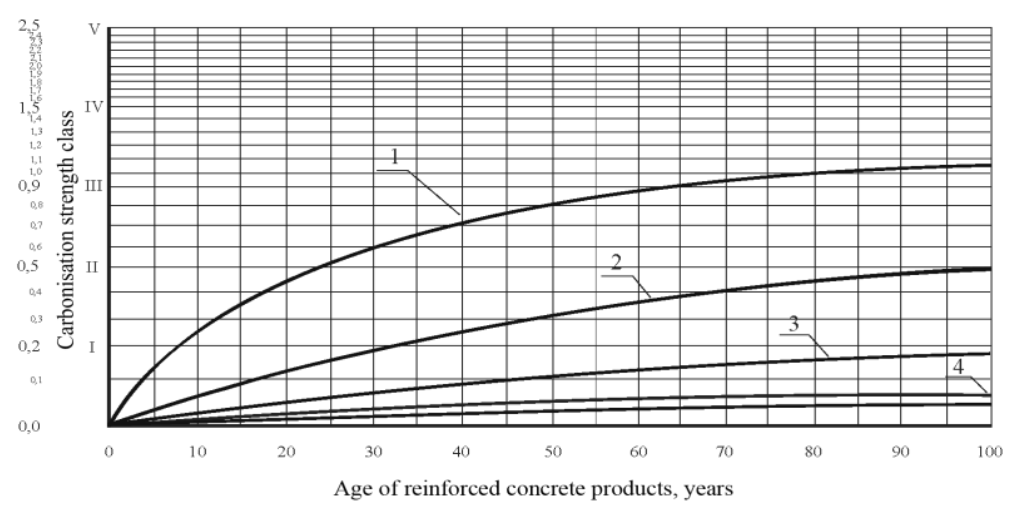

The thickness of the protective layer of concrete: $1-10 ; 2-15 ; 3-20 ; 4-25 \mathrm{~mm}$

Figure 2. Dependences of the depth of steel reinforcement corrosion damage on the thickness of the protective layer of concrete strength class $\mathrm{C}^{25 /}{ }_{30}$ for the open atmosphere conditions 


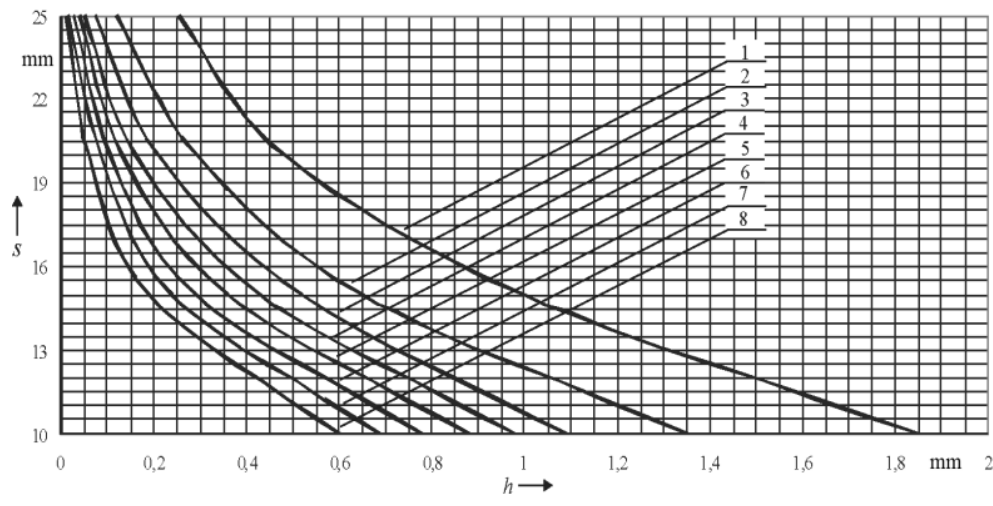

Concrete compressive strength classes: $1-\mathrm{C}^{12 / 15} ; 2-\mathrm{C}^{16 / 20} ; 3-\mathrm{C}^{18 / 22.5} ; 4-\mathrm{C}^{20 / 25} ; 5-\mathrm{C}^{22 / 27,5} ; 6-\mathrm{C}^{25 / 30} ; 7-\mathrm{C}^{28 / 35} ; 8-\mathrm{C}^{30 / 37}$

Figure 3. Regression dependences of the depth of corrosion of steel reinforcement on the thickness of the protective layer of concrete (for operating conditions in an open atmosphere)

Based on them, regression dependences of the average rate of corrosion damage of steel reinforcement on the thickness of the concrete protective layer were obtained (for concrete of various classes in strength and operating conditions of an open atmosphere). Graphically they are presented in Figure 4.

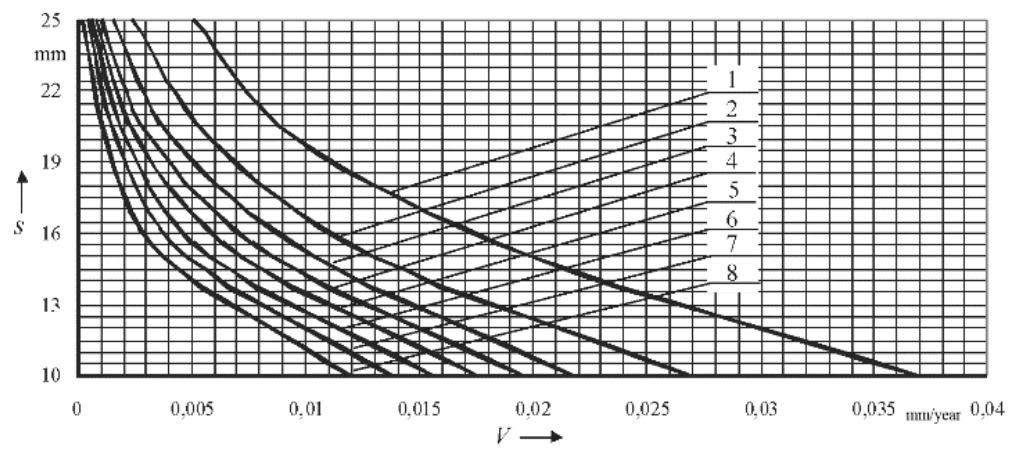

Concrete compressive strength classes: $1-\mathrm{C}^{12 / 15} ; 2-\mathrm{C}^{16 / 20} ; 3-\mathrm{C}^{18 / 22.5} ; 4-\mathrm{C}^{20 / 25} ; 5-\mathrm{C}^{22 / 27,5} ; 6-\mathrm{C}^{25 / 30} ; 7-\mathrm{C}^{28 / 35} ; 8-\mathrm{C}^{30 / 37}$

Figure 4. Regression dependences of the average corrosion rate of steel reinforcement on the thickness of the concrete protective layer for operating conditions in the open atmosphere

The dependencies obtained show that:

-the corrosion rate of steel reinforcement in carbonised concrete is the same for all strength classes of concrete (decreases along the cross section from the surface into the depth, acc. to the complex exponential dependence pattern);

- the corrosion rate depends on the strength class of concrete (the higher the strength class, the lower the corrosion rate).

The nature of dependencies and the physical meaning of the problem of assessing the depth of damage of steel reinforcement made it possible to suggest (in general terms) a regression dependence of the rate of damage of steel reinforcement for fixed values of the thickness of the protective layer of concrete and the exponential nature of corrosion development in steel reinforcement:

$$
h(t)=\alpha_{0}\left(1-\exp \left(-\alpha_{1} t\right)\right)
$$

where: $h$ is the corrosion depth of steel reinforcement, $\mathrm{mm} ; t$ is the operating time, years; $\alpha_{0}$ and $\alpha_{1}$ are the coefficients that determine: the maximum corrosion rate at $t=\infty\left(\alpha_{0}\right)$ and the rate of development of the corrosion process $\left(\alpha_{1}\right)$.

When establishing the given regression dependence, the boundary value of the operation of 100 years was taken.

The coefficients $\alpha_{0}$ and $\alpha_{1}$ were determined automatically by the least squares method under the Nonlinear Regression section of the Statgraphics Centurion software package for statistical data analysis. The solution of the corresponding system of nonlinear equations was carried out by the Marquardt method.

To find the dependence of the development of corrosion of steel reinforcement on the thickness of the concrete protective layer, it was necessary to obtain the dependence of the parameters $\mathrm{a}_{0}$ and $\mathrm{a}_{1}$ (over four thicknesses of the protective layer) for any value of the protective layer (s). 
Using regression analysis methods for scattering diagrams $\mathrm{a}_{0}(\mathrm{~s})$ and $\mathrm{a}_{1}(\mathrm{~s})$, it was found that these dependences are effectively described by approximating hyperbole equations:

$$
\begin{aligned}
& \mathrm{a}_{0}(s)=b_{0}+b_{1} / s, \\
& \mathrm{a}_{1}(s)=c_{0}+c_{1} / s,
\end{aligned}
$$

where: $b_{0}, b_{1}, c_{0}, c_{1}$ - coefficients; $s$ - thickness of the protective layer of concrete, $\mathrm{mm}$.

Thus, the depth of corrosion in steel reinforcement for any thickness of the protective layer

$$
h(t, s)=\left(b_{0}+\frac{b_{1}}{s}\right)\left\{1-\exp \left[-\left(c_{0}+\frac{c_{1}}{s}\right) t\right]\right\} .
$$

Hyperbole parameters were determined automatically under the Simple Regression section of the Statgraphics Centurion package using the least squares method.

The obtained values of the coefficients $b_{0}, b_{1}, c_{0}, c_{1}$ for strength grades of concrete on compression $\mathrm{C}^{12} / 15-\mathrm{C}^{30} / 37$, in open atmosphere conditions, are shown in Table 1.

Table 1. Values of indicators $b_{0}, b_{1}, c_{0}$ and $c_{1}$

\begin{tabular}{|c|c|c|c|c|}
\hline \multirow{2}{*}{$\begin{array}{c}\text { Concrete grade by strength on } \\
\text { compression }\end{array}$} & \multicolumn{4}{|c|}{ Coefficient } \\
\cline { 2 - 5 } & $b_{0}$ & $b_{1}$ & $c_{0}$ & $c_{1}$ \\
\hline $\mathrm{C}^{12 / 15}$ & -0.745000 & 33.250000 & 0.00299648 & 0.3520030 \\
\hline $\mathrm{C}^{16 / 20}$ & -0.695000 & 23.750000 & 0.0003100 & 0.4100000 \\
\hline $\mathrm{C}^{18 / 22.5}$ & -0.562000 & 19.990000 & -0.0019900 & 0.3300000 \\
\hline $\mathrm{C}^{20} / 25$ & -0.621000 & 20.519000 & -0.0035000 & 0.2860000 \\
\hline $\mathrm{C}^{22} / 27,5$ & -0.537000 & 18.560000 & -0.0048000 & 0.2560000 \\
\hline $\mathrm{C}^{25} / 30$ & -0.422000 & 14.995000 & -0.0052000 & 0.2520000 \\
\hline $\mathrm{C}^{28} / 35$ & -0.293000 & 11.395000 & -0.0052500 & 0.2299000 \\
\hline $\mathrm{C}^{30 / 37}$ & -0.235000 & 9.589000 & -0.0052880 & 0.2050000 \\
\hline
\end{tabular}

Rate of corrosion of steel reinforcement in carbonised concrete

$$
v(t, s)=\left(b_{0}+\frac{b_{1}}{s}\right)\left(c_{0}+\frac{c_{1}}{s}\right) \cdot\left[-\left(c_{0}+\frac{c_{1}}{s}\right) t\right] .
$$

The analysis of results of determining the corrosion rate of steel reinforcement (for any strength classes of concrete) shows that:

- the corrosion rate decreases over the cross section of concrete from the surface, towards its depth, acc. to a complex dependence pattern;

- the corrosion rate, starting from the thickness of the concrete protective layer of less than $20 \mathrm{~mm}$, is significantly higher than that proposed today in (DuraCrete 7, 1999) and is equal to $0.005 \mathrm{~mm} / \mathrm{year}$ in carbonised concrete.

\section{Conclusions}

The studies performed and the regression dependences obtained from their results allow to evaluate and predict the depth and rate of corrosion damage of steel reinforcement depending on the strength class of concrete and the thickness of the protective layer.

Their use allows to significantly more objectively predict the durability of reinforced concrete culverts in terms of degradation of reinforced concrete, both at the design stage and in operation.

\section{References}

Alekseev, S. N., \& Rozental', N. K. (1976). Korrozionnaya stoykost'zhelezobetonnykh konstruktsiy v agressivnoy promyshlennoy srede. Stroyizdat.

Babushkin, V. I., Matveev, G. M., \& Mchedlov-Petrosyan, O. P. (1986). Termodinamika silikatov. Stroyizdat.

DuraCrete 7. (1999). General guidelines for durability design and redesign. The European Union - Brite EuRam III (Project No. BE95-1347), Probabilistic performance-based durability design of concrete structures (Report No. T7-01-1). 
Kudryavtsev, I. A., \& Bogdanov, V. P. (2001). Issledovanie ravnomernosti glubiny zaleganiya karbonizirovannogo sloya po glubine v balke proletnogo stroeniya. In Problemy tekhnologii proizvodstva stroitel'nykh materialov, izdeliy $i$ konstruktsiy, stroitel'stva zdaniy i sooruzheniy, podgotovki inzhenernykh kadrov dlya stroitel'noy otrasli: materialy VII Mezhdunar. nauch.prakt. Seminara (S. 227-229). Strinko.

Vasil'yev, A. A. (2012). Karbonizatsiya i otsenka povrezhdennosti zhelezobetonnykh konstruktsiy (monografiya). BelGUT.

Vasil'yev, A. A. (2013). Karbonizatsiya betona (otsenka i prognozirovanie) (monografiya). BelGUT.

Vasil'yev, A. A. (2016). Raschetno-eksperimental'naya model' karbonizatsii betona (monografiya). BelGUT.

Vasil'yev, A. A. (2017). Sovershenstvovanie otsenki i prognozirovaniya tekhnicheskogo sostoyaniya zhelezobetonnykh elementov i konstruktsiy, ekspluatiruyushchikhsya v razlichnykh atmosfernykh usloviyakh. In Problemy sovremennogo betona $i$ zhelezobetona (S. 148-167). Minsk.

Vasil'yev, A. A. (2018). Otsenka i prognozirovanie stepeni karbonizatsii betona. In G. Yu. Gulyaeva (Ed.), Innovatsionnoe razvitie: potentsial nauki i sovremennogo obrazovaniya (S. 148-158). MTsNS "Nauka i prosveshchenie".

Vasil'yev, A. A. (2019). Otsenka i prognozirovanie tekhnicheskogo sostoyaniya zhelezobetonnykh konstruktsiy s uchetom karbonizatsii betona (monografiya). BelGUT. 